\title{
Hepatitis $C$ virus infection and risk of cancer: a population-based cohort study
}

This article was published in the following Dove Press journal:

Clinical Epidemiology

24 June 2010

Number of times this article has been viewed

\author{
Lars Haukali Omland' \\ Dora Körmendiné Farkas ${ }^{2}$ \\ Peter Jepsen ${ }^{2,3}$ \\ Niels Obel' \\ Lars Pedersen ${ }^{2}$ \\ 'Department of Infectious Diseases, \\ Rigshospitalet, Denmark; ${ }^{2}$ Department \\ of Clinical Epidemiology, ${ }^{3}$ Department \\ of Medicine V (Hepatology and \\ Gastroenterology), Aarhus University \\ Hospital, Denmark
}

Correspondence: Lars Haukali Omland Department of Infectious Diseases, Rigshospitalet, Blegdamsvej 9, DK2I 00 Copenhagen $\varnothing$, Denmark

$\mathrm{Tel}+4535457726$

$\mathrm{Fax}+4535456648$

Email omland@dadlnet.dk
Background: Hepatitis $\mathrm{C}$ virus (HCV) infection is associated with an increased risk of primary liver cancer; however, 5- and 10-year risk estimates are needed. The association of HCV with nonHodgkin lymphoma (NHL) is uncertain and the association with other cancers is unknown.

Method: We conducted a nationwide, population-based cohort study of 4,349 HCV-infected patients in Denmark, computing standardized incidence ratios (SIR) of cancer incidence in HCV infected patients compared with cancer incidence of the general population. We calculated 5and 10-year risks of developing cancer, stratifying our analyses based on the presence of HIV coinfection and cirrhosis.

Results: We recorded an increased risk of primary liver cancer (SIR: 76.63 [95\% CI: 51.69-109.40]), NHL (SIR: 1.89 [95\% CI: 0.39-5.52]), and several smoking- and alcohol-related cancers in $\mathrm{HCV}$ infected patients without HIV coinfection. HCV-infected patients without HIV coinfection had a $6.3 \%(95 \% \mathrm{CI}: 4.6 \%-8.7 \%)$ risk of developing cancer and $2.0 \%(95 \% \mathrm{CI}$ : $1.1 \%-3.8 \%$ ) risk of developing primary liver cancer within 10 years.

Conclusion: We confirmed the association of HCV infection with primary liver cancer and NHL. We also observed an association between HCV infection and alcohol- and smoking-related cancers.

Keywords: hepatitis C virus, non-Hodgkin lymphoma, standardized incidence ratio, cancer

The association between hepatitis $\mathrm{C}$ virus (HCV) infection and the risk of hepatocellular carcinoma (HCC) was established in case control studies, ${ }^{1-3}$ soon after the discovery of $\mathrm{HCV}^{4}$ in 1989. Recent large scale cohort studies in Australia ${ }^{5}$ and Sweden ${ }^{6}$ have yielded differing estimates of the risk of $\mathrm{HCC}$ in $\mathrm{HCV}$ infected patients ranging from a 23-fold to a 35-fold increased risk. Only in the Australian study were the risk estimates for HIV coinfection adjusted (by excluding data from high HIV prevalence postcodes of residence), only in the Swedish study were absolute risk estimates of cancer provided, and in none of these was information on cirrhosis at baseline provided. Therefore, areas of uncertainty still exist. Further, the relative risk of developing primary liver cancer increases in relation to time of $\mathrm{HCV}$ infection, making the risk estimates dependent on the particular HCV epidemiology of the particular region. ${ }^{6}$ Therefore estimates of the association between $\mathrm{HCV}$ and primary liver cancer need to be examined in several study settings.

It is unclear whether HCV infection increases the risk of non-Hodgkin lymphoma (NHL); HCV infection has been associated with NHL in some, ${ }^{7,8}$ but not all, studies. ${ }^{5}$ In two meta analyses, the association differed depending on HCV prevalence in the study population and study designs. ${ }^{9,10}$ Examining whether there is an association in 
new nationwide, population-based settings therefore is of great importance.

$\mathrm{HCV}$ infection is often associated with a number of lifestyle factors, particularly in drug users who consume drugs via injections. ${ }^{11,12}$ Therefore, HCV-infected patients could be at increased risk of getting cancer, not only due to the pathogenic effect of the virus, ${ }^{13,14}$ but also due to a higher degree of exposure to alcohol abuse and smoking than those in the general population. ${ }^{15-19}$

We therefore undertook a nationwide, population-based cohort study with long term follow up to estimate the relative risk of development of cancers in $\mathrm{HCV}$ infected persons presenting to the hospital system compared to the general population. We expected an increased risk of primary liver cancer, of smoking- and alcohol-related cancers, and possibly of NHL, but not of other cancers in comparison to the general population. We estimated absolute risks of primary liver cancer, adjusting for HIV coinfection and including information on cirrhosis. These data are needed to foster our understanding of the clinical course of $\mathrm{HCV}$ infection.

\section{Method}

We used the unique 10 digit civil registration number assigned to all individuals in Denmark to link the databases discussed below. ${ }^{20}$

\section{The Danish National Hospital Registry}

Since its inception in 1977, the Danish National Hospital Registry (DNHR) has collected data from all inpatient admissions to non-psychiatric hospitals in Denmark. ${ }^{21}$ Data from outpatient and emergency department visits were added in 1995. Each admission record includes the dates of admission (or start of an outpatient contact), date of discharge, and up to 20 diagnoses (one of which is designated as the primary diagnosis), classified according to the Danish version of the international classification of diseases, 8th revision (ICD-8) until Dec 31, 1993, and 10th version (ICD-10) thereafter. Diagnoses are coded by the treating physician. As HCV was discovered in 1989, it does not have a separate code in the ICD-8 (however acute HCV was often coded as non-A, non-B acute hepatitis), but in ICD-10 both acute and chronic HCV infections have separate codes.

\section{The Danish Cancer Registry}

The Danish Cancer Registry has recorded data on all cancers diagnosed in Denmark since $1943 .{ }^{22}$ Cancers are classified according to the modified Danish version of the international classification of diseases, 7th revision (ICD-7) by hospital departments and practising physicians. Comprehensive assessment has shown the registry to be $95 \%-98 \%$ complete and valid. ${ }^{22}$

\section{Study population}

We included all people listed in DNHR with at least one diagnosis of acute or chronic HCV infection (ICD-10 B17.1 and 18.2) between 1994 and 2003 (inclusive). Through links to the cancer registry, we excluded patients who had had a previous diagnosis of cancer.

\section{Statistical analyses}

We followed cases for the occurrence of cancer from the date of first registration of HCV in DNHR (admission, outpatient clinic, or emergency department) until the date of death, emigration, or HIV coinfection or until Dec 31, 2003, whichever came first. We censored HCV infected patients at time of HIV coinfection, as HIV infection is associated with several cancers (including NHL and primary liver cancer) and because our main objective was to describe the risk of cancer in $\mathrm{HCV}$ infected patients, and not in HIV-HCV coinfected patients. ${ }^{23,24}$ We calculated the expected number of cases of cancer after a diagnosis of $\mathrm{HCV}$ infection using Danish incidence rates of first cancer diagnoses according to sex, age, and year of diagnosis in 1-year intervals. Multiplication of the number of years of follow-up by the incidence rates yielded the number of people with cancer that would be expected if patients with $\mathrm{HCV}$ infection had the same rate of cancer as the general population. ${ }^{25}$ We used the standardised incidence ratio - the ratio of observed number of cancers to expected number of cancers - to measure the association between HCV infection and cancer, and calculated a $95 \% \mathrm{CI}$ on the basis of the assumption that the observed number of cancers in a specific category followed a Poisson distribution. Exact 95\% CI were used throughout the study, unless the observed number of cancers was 10 or more, in which case Byar's correction was used. ${ }^{26}$ For cancer sites with 5 or more recorded cases, SIRs were further computed for the first year of observation and for the second year of observation and onwards. Cancers were divided into the following subgroups as specified in Appendix 1: Hematological cancers, liver-related cancers, alcohol- and tobacco-related cancers, immune-related cancers, and other cancers. We stratified our analyses according to whether the patients had been previously diagnosed with HIV, since HIV coinfection has a substantial impact on morbidity and mortality in HCV coinfected patients. ${ }^{27-29}$ For those not previously infected with HIV, we stratified our 
analyses according to whether the first $\mathrm{HCV}$ diagnosis was acute $\mathrm{HCV}$ infection or chronic HCV infection and whether or not they had cirrhosis at baseline. We estimated cumulative risks using the life-table method.

\section{Results}

We identified a total of 4,349 patients with HCV infection in the DNHR. Median age at diagnosis was 39.9 years and median follow up was 3.3 years (interquartile range [IQR] 1.3-5.7). A total of 2,721 (63\%) of patients were males. There were 4,043 patients (93\%) aged between 20 and 60 years of age at study entry. A total of 105 incident cancers were recorded during 16,267 years of observation. During follow up, 19 patients were diagnosed with HIV.

\section{HCV-infected patients without HIV coinfection at baseline Overall cancer}

A total of 100 cancers were recorded during 15,980 years of observation in the 4,204 HCV-infected patients without HIV coinfection at baseline (SIR [standardized incidence ratio]: 1.78, 95\% CI: 1.45-2.17). Of these 4,204 patients, 507 were diagnosed with acute $\mathrm{HCV}$ infection and the remaining 3,697 were diagnosed with chronic HCV infection. In these groups, 14 and 86 cancers were recorded with corresponding SIRs of 1.88 (95\% CI: 1.03-3.15) and 1.77 (95\% CI: 1.42-2.19), respectively. All cancers recorded in $\mathrm{HCV}$-infected patients without HIV at baseline are illustrated in Table 2. In Table 3 the most frequently recorded cancers ( $\geq 5$ recorded cancers) are recorded for the $\mathrm{HCV}$ infected patients without HIV at baseline, and in Table 4 the most frequently recorded cancers ( $\geq 5$ recorded cancers) are illustrated for the chronically
HCV-infected patients without HIV at baseline. HCV infection was associated with cancers in all age groups and both sexes were at increased risk of cancer (Table 1). Men who were infected with $\mathrm{HCV}$, however, had a more than 2-fold increased risk whereas women who were infected with $\mathrm{HCV}$ had a 1.4-fold increased risk of cancer. The absolute 5- and 10-year risks of developing all-type cancer in HCV-infected patients without HIV was $2.9 \%$ (95\% CI: $2.3-3.7 \%$ ) and $6.3 \%$ (95\% CI: $4.6 \%-8.7 \%$ ). The SIR of cancer in patients with a diagnosis of cirrhosis at time of HCV diagnosis was 1.64 (95\% CI: 1.31-2.03) whereas the SIR of cancer in patients without cirrhosis was 3.27 (95\% CI: 1.87-5.31).

\section{Liver cancer}

Compared to the general population, $\mathrm{HCV}$ infection was associated with a 77-fold increase in risk of primary liver cancers. For women, the expected number of cases was 0.10 and the observed number of cases was 10 (SIR: 101.83, 95\% CI: 48.75-187.29). For men the expected number of cases was 0.29 and the observed number of cases was 20 (SIR: 68.19, 95\% CI: 41.64-105.33). No primary liver cancers were recorded in patients under the age of 30; in all other age groups there was an increased risk of primary liver cancers (not shown). Also non-primary liver cancer was associated with HCV infection. The absolute 5- and 10-year risks of developing primary liver cancer in $\mathrm{HCV}$-infected patients without HIV was $0.8 \%(95 \% \mathrm{CI}: 0.5 \%-1.2 \%)$ and $2.0 \%(95 \%$ CI: $1.1 \%-3.8 \%$ ). The SIR of primary liver cancer in patients with a diagnosis of cirrhosis at time of HCV diagnosis was 53.88 (95\% CI: 32.43-84.15) whereas the SIR of primary liver cancer in patients without cirrhosis was $288.99(95 \%$ CI: 144.07-517.12).

Table I Standardized incidence ratios (SIR) for all cancers after a diagnosis of HCV infection (in patients without HIV) according to sex and age at the time of admission

\begin{tabular}{|c|c|c|c|c|}
\hline & $\begin{array}{l}\text { Number of patients } \\
\text { with HCV infection }\end{array}$ & $\begin{array}{l}\text { Number of } \\
\text { cancers observed }\end{array}$ & $\begin{array}{l}\text { Number of } \\
\text { cancers expected }\end{array}$ & SIR (O/E) \\
\hline Total & 4,204 & 100 & 56.12 & $1.78(1.45-2.17)$ \\
\hline \multicolumn{5}{|c|}{ Acute vs chronic HCV infection } \\
\hline Acute & 507 & 14 & 7.45 & $1.88(1.03-3.15)$ \\
\hline Chronic & 3,697 & 86 & 48.57 & $1.77(1.42-2.19)$ \\
\hline \multicolumn{5}{|l|}{ Sex } \\
\hline Women & 1577 & 38 & 27.24 & $1.39(0.99-1.91)$ \\
\hline Men & 2627 & 62 & 28.88 & $2.15(1.65-2.75)$ \\
\hline \multicolumn{5}{|c|}{ Age (years) ${ }^{\dagger}$} \\
\hline $0-29$ & 717 & 3 & 1.10 & $2.74(0.56-7.99)$ \\
\hline $30-49$ & 2,766 & 41 & 23.04 & $\mathrm{I} .78(\mathrm{I} .28-2.4 \mathrm{I})$ \\
\hline $50-69$ & 610 & 34 & 22.23 & $1.53(1.06-2.14)$ \\
\hline $70+$ & 111 & 22 & 9.74 & $2.26(\mathrm{I} .4 \mathrm{I}-3.42)$ \\
\hline
\end{tabular}

${ }^{\dagger}$ Age at time of diagnosis of $\mathrm{HCV}$ infection. 
Table 2 All observed cancers in HCV-infected patients without HIV at baseline and corresponding standardized cancer incidence ratios

\begin{tabular}{|c|c|c|c|}
\hline & Observed & Expected & $\begin{array}{l}\text { Standardized incidence } \\
\text { ratio }(95 \% \mathrm{Cl})\end{array}$ \\
\hline All neoplasms I40-205 & 100 & 56.12 & $1.78(1.45-2.17)$ \\
\hline \multicolumn{4}{|l|}{ Hematological cancers } \\
\hline Non-Hodgkin lymphoma $(200,202)$ & 3 & 1.59 & $1.89(0.39-5.52)$ \\
\hline Leukemia (204) & I & 1.17 & $0.85(0.02-4.74)$ \\
\hline \multicolumn{4}{|l|}{ Liver cancer } \\
\hline Liver, primary (I55.0) & 30 & 0.39 & $76.63(51.69-109.40)$ \\
\hline Liver, not specified as primary (156) & 3 & 0.38 & $7.84(1.62-22.90)$ \\
\hline \multicolumn{4}{|l|}{ Alcohol- and tobacco-related cancers } \\
\hline Oropharyngeal (|40-|48) & 4 & 1.73 & $2.32(0.63-5.93)$ \\
\hline Esophagus (150) & I & 0.60 & $1.65(0.04-9.22)$ \\
\hline Colon, including recto sigmoid (I53) & 3 & 2.95 & $1.02(0.2 \mathrm{I}-2.97)$ \\
\hline Rectum, excluding anus (I54) & 3 & 1.63 & $1.85(0.38-5.39)$ \\
\hline Pancreas (157) & 4 & 1.01 & $3.95(1.07-10.11)$ \\
\hline Lung (I62.0-162.I) & 10 & 5.14 & $1.95(0.93-3.58)$ \\
\hline Kidney (180) & 4 & 1.11 & $3.60(0.98-9.22)$ \\
\hline Bladder (I8I) & 2 & 2.18 & $0.92(0 .||-3.3 \mid)$ \\
\hline \multicolumn{4}{|l|}{ Immune-related cancers } \\
\hline Cervix uteri (I7I) & I & 1.30 & $0.77(0.02-4.29)$ \\
\hline Melanoma of skin (190) & I & 2.99 & $0.33(0.01-1.86)$ \\
\hline Other skin (191) & 9 & 10.60 & $0.85(0.39-1.61)$ \\
\hline \multicolumn{4}{|l|}{ Other cancers* } \\
\hline Gallbladder (I55.I) & I & 0.19 & $5.25(0.13-29.22)$ \\
\hline Peritoneum and unspecified (I58-159) & I & 0.11 & $9.34(0.24-52.01)$ \\
\hline Mediastinum (164) & 1 & 0.05 & $21.22(0.54-118.22)$ \\
\hline Breast (I70) & 2 & 8.05 & $0.25(0.03-0.90)$ \\
\hline Corpus uteri (I72) & I & 0.83 & $1.21(0.03-6.72)$ \\
\hline Ovary (I75) & 1 & 1.07 & $0.94(0.02-5.21)$ \\
\hline Prostate (I77) & 2 & 1.95 & $1.02(0.12-3.70)$ \\
\hline Testis (178) & 1 & 1.59 & $0.63(0.02-3.5 \mathrm{I})$ \\
\hline Other and unspecified male genitals (I79) & 1 & 0.10 & $9.71(0.25-54.06)$ \\
\hline Brain and nervous system (193) & 5 & 2.40 & $2.08(0.68-4.86)$ \\
\hline Thyroid (194) & 1 & 0.46 & $2.16(0.05-12.01)$ \\
\hline Metastases (198) & 2 & 0.62 & $3.23(0.39-11.66)$ \\
\hline Other and unspecified site (199) & 2 & 0.58 & $3.43(0.42-12.39)$ \\
\hline
\end{tabular}

\section{Hematological cancers}

HCV-infected patients carried a doubled risk of NHL; however the $95 \%$ CI margins were very wide for this estimate.

\section{Alcohol and tobacco-related cancers}

Cancers of the pancreas, lungs, kidneys, and oropharyngeal region were associated with $\mathrm{HCV}$ infection. Lung cancers represented most recorded cases, with 9 cases among men (SIR: 2.90, 95\% CI: $1.33-5.50$ ) and 1 case among women (SIR: 0.49, 95\% CI: 0.01-2.74).

\section{Immune-related and other cancers}

There was no convincing association between HCV infection, immune-related cancers, and other cancers.

\section{HCV-infected patients with HIV coinfection at baseline}

Five cancers were recorded during 288 years of follow up in the 145 patients who were HIV coinfected at baseline (SIR: 8.9, 95\% CI: $2.9-20.6)$. These were primary liver cancer ( $\mathrm{n}=1$, SIR: $319.08,95 \%$ CI: 8.07-1,777.03), other skin cancers than melanoma ( $\mathrm{n}=1$, SIR: 9.04, 95\% CI: 0.23-50.36), NHL $(n=2$, SIR: 99.72, 95\% CI: 12.07-359.97), and oropharyngeal cancer ( $\mathrm{n}=1$, SIR: $50.35,95 \%$ CI: 1.27-280.46).

\section{Discussion}

Our results indicate that $\mathrm{HCV}$ infected patients have an increased risk of cancer compared to the general population with a 10 -year risk of about $6 \%$. The increased risk of cancer was mainly due to a few cancer types, most prominently 
Table 3 Standardized cancer incidence ratios (SIR) for HCVinfected patients without HIV at baseline

\begin{tabular}{|c|c|c|c|c|}
\hline & \multicolumn{2}{|c|}{$\begin{array}{l}\text { First year after } \\
\mathrm{HCV} \text { diagnosis }\end{array}$} & \multicolumn{2}{|c|}{$\begin{array}{l}\text { More than I year } \\
\text { after HCV } \\
\text { diagnosis }\end{array}$} \\
\hline & $\overline{\mathbf{N}}$ & SIR (95\% CI) & $\mathbf{N}$ & SIR (95\% CI) \\
\hline All cancer & 33 & $\begin{array}{l}2.92 \\
(2.01-4.10)\end{array}$ & 67 & $\begin{array}{l}1.50 \\
(1.16-1.90)\end{array}$ \\
\hline Liver, primary & 12 & $\begin{array}{l}152.64 \\
(78.78-266.65)\end{array}$ & 18 & $\begin{array}{l}57.53 \\
(34.08-90.93)\end{array}$ \\
\hline Lung & 2 & $\begin{array}{l}1.98 \\
(0.24-7.13)\end{array}$ & 8 & $\begin{array}{l}1.94 \\
(0.84-3.82)\end{array}$ \\
\hline $\begin{array}{l}\text { Non-melanoma } \\
\text { skin cancer }\end{array}$ & 2 & $\begin{array}{l}0.95 \\
(0.12-3.44)\end{array}$ & 7 & $\begin{array}{l}0.82 \\
(0.33-1.70)\end{array}$ \\
\hline $\begin{array}{l}\text { Brain and nervous } \\
\text { system }\end{array}$ & I & $\begin{array}{l}1.92 \\
(0.05-10.69)\end{array}$ & 4 & $\begin{array}{l}2.13 \\
(0.58-5.45)\end{array}$ \\
\hline
\end{tabular}

"Sites with 5 or more recorded cancers.

primary liver cancer with an estimated 10 -year risk of $2 \%$. Further, HCV infection was associated with NHL and cancers related to smoking and alcohol use (cancers of the pancreas, lungs, kidneys, and oropharyngeal region).

\section{Limitations}

Our study has some limitations. Due to the subclinical nature of $\mathrm{HCV}$, some infections go unrecognized ${ }^{30}$ resulting in underreporting of $\mathrm{HCV}^{31,32}$ Such underreporting of $\mathrm{HCV}$ infection could influence the estimated associations we recorded, if those who were not reported were at a different risk of cancers compared to those who were recorded. While underreporting might have some influence on our results, we find it unlikely that underreporting is the main explanation of our findings. As another consequence of the subclinical nature of HCV, we lacked data on dates of infection/seroconversion. ${ }^{33}$ This could have exaggerated our SIR estimates, if patients were diagnosed with $\mathrm{HCV}$ infection on diagnosis of the initial symptoms of cancer. This is certainly possible, given the finding that SIRs for all cancer types and for liver

Table 4 Standardized cancer incidence ratios (SIR) for patients with chronic HCV infection without HIV

\begin{tabular}{|c|c|c|c|c|}
\hline & \multicolumn{2}{|c|}{$\begin{array}{l}\text { First year after } \\
\text { HCV diagnosis }\end{array}$} & \multicolumn{2}{|c|}{$\begin{array}{l}\text { More than I year } \\
\text { after HCV } \\
\text { diagnosis }\end{array}$} \\
\hline & $\overline{\mathbf{N}}$ & SIR (95\% CI) & $\mathbf{N}$ & SIR (95\% CI) \\
\hline All cancer & 31 & $\begin{array}{l}3,05 \\
(2.07-4.33)\end{array}$ & 55 & $\begin{array}{l}1.43 \\
(1.08-1.86)\end{array}$ \\
\hline Liver, primary & II & $\begin{array}{l}153.01 \\
(76.28-273.80)\end{array}$ & 14 & $\begin{array}{l}51.48 \\
(28.12-86.38)\end{array}$ \\
\hline Lung & 2 & $\begin{array}{l}2.17 \\
(0.26-7.85)\end{array}$ & 7 & $\begin{array}{l}1.95 \\
(0.78-4.02)\end{array}$ \\
\hline $\begin{array}{l}\text { Non-melanoma } \\
\text { skin cancer }\end{array}$ & 2 & $\begin{array}{l}1.06 \\
(0.13-3.81)\end{array}$ & 6 & $\begin{array}{l}0.82 \\
(0.30-1.79)\end{array}$ \\
\hline
\end{tabular}

"Sites with 5 or more recorded cancers. cancer were greater in the first year of diagnosis compared to the following years; however, we find it unlikely that this phenomenon is the main explanation of our findings, as SIRs remained elevated also beyond 1 year of observation. Further, our estimates are useful from a clinical point of view, as they describe the risk of cancer upon diagnosis. A final concern could be that the observed associations could represent surveillance/diagnostic bias (ie, differential misclassification of outcome).${ }^{34}$ However, we could not demonstrate any association between $\mathrm{HCV}$ infection and immune related cancers which speaks against surveillance/diagnostic bias as a general phenomenon explaining our results. ${ }^{35}$ By censoring patients at time of HIV coinfection we may have introduced informative censoring, causing us to underestimate $\mathrm{HCV}$ infected patients' risk of non-Hodgkin lymphoma, for which HIV is a strong risk factor. ${ }^{23,24}$ However, only 19 patients were censored because of HIV coinfection, so - considering the size and direction of this bias - it could not have had a clinically significant impact on our conclusions.

\section{Discussion of our results and the literature}

We recorded a substantially increased risk of primary liver cancer. Thereby we corroborate the findings from other population-based studies in Sweden and Australia., 5,6 Our overall SIR was 2-fold that of the Swedish study and our SIR from the second year of observation and onwards was approximately 2.5 -fold that of the Australian study. ${ }^{5,6}$ Different risks of cancer in the general population in Australia, Sweden, and Denmark, and differences in HCV notification, age at inclusion, and time with infection prior to diagnosis (and thereby study inclusion) in these two studies and ours are possible explanations for these differences. Moreover, none of the studies (ours or those taken from the literature) included data on active HCV replication, and differences in the proportion that cleared the infection might explain the differences in the SIRs recorded. Finally, differences in the proportion of patients with alcohol abuse could explain the higher risks of liver cancer in our study. ${ }^{36}$ The recorded 5-year risk of liver cancer in our study $(<1 \%)$ was much smaller than the 5 year risk of approximately $5 \%$ in the HALT-C Trial. ${ }^{37}$ This difference potentially reflects the more advanced stage of $\mathrm{HCV}$ infection in patients included in the HALT-C Trial compared to our study. However, risk estimates from population based settings as ours are important, as they apply for the patient upon diagnosis. Surprisingly, HCV infected patients without cirrhosis were at an exceptionally high risk of primary liver cancer. The reason for this is not clear. Probably some of these 
patients were in fact cirrhotic at the time of HCV diagnosis, presenting at an advanced stage of liver disease.

We observed an increased risk of NHL in HCV infected patient without HIV, which confirms the findings of others. ${ }^{7-10}$ This association could be caused by lifestyle factors in the HCV-infected population, a causal effect of the HCV infection or both. ${ }^{8,38-41}$ Importantly, we were able to address the issue of HIV coinfection. NHL is an AIDS defining illness, and is highly associated with HIV. ${ }^{23}$ The importance of incorporating HIV coinfection in the risk analysis is illustrated by a 100-fold increased risk in the coinfected group and 2-fold increased risk in the HCV monoinfected patients compared to the general population.

We observed an increased risk of cancers related to smoking and alcohol (cancers of the pancreas, lungs, kidneys, and oropharyngeal region). Most likely, the increased risk of these cancers represents a higher prevalence of alcohol abuse and smoking in the HCV-infected patients compared to the general population. ${ }^{11,12,15-19,42,43}$ However, our data sources included only DNHR diagnosis and no further clinical data. Therefore we were unable to address the potential effects of alcohol abuse and smoking in our study. Lung cancers were the most frequently recorded smoking-related cancer, with men, but apparently not women, at increased risk. This could indicate an uneven distribution of smoking in the two groups.

\section{Conclusion}

In summary, we found an association between $\mathrm{HCV}$ infection and cancer, mainly by confirming the well-established association between HCV infection and primary liver cancer. We also rendered support to the suggested association between HCV infection and NHL. Finally, we found HCV infection to be associated with a range of smoking- and alcohol-related cancers (cancers of the pancreas, lungs, kidneys, and oropharyngeal region) but not with any other cancers.

\section{Acknowledgments}

The study received financial support from the Karen Elise Jensen Foundation. The sponsor of the study had no role in the study design, in the collection, analysis, and interpretation of the data, or in the writing of the report.

\section{Disclosure}

The authors report no conflict of interest in this work.

\section{References}

1. Bruix J, Barrera JM, Calvet X, et al. Prevalence of antibodies to hepatitis $\mathrm{C}$ virus in Spanish patients with hepatocellular carcinoma and hepatic cirrhosis. Lancet. 1989;2:1004-1006.
2. Colombo M, Kuo G, Choo QL, et al. Prevalence of antibodies to hepatitis $\mathrm{C}$ virus in Italian patients with hepatocellular carcinoma. Lancet. 1989;2:1006-1008.

3. Simonetti RG, Cottone M, Craxi' A, et al. Prevalence of antibodies to hepatitis C virus in hepatocellular carcinoma. Lancet. 1989;2:1338.

4. Choo QL, Kuo G, Weiner AJ, Overby LR, Bradley DW, Houghton M. Isolation of a cDNA clone derived from a blood-borne non-A, non-B viral hepatitis genome. Science. 1989;244:359-362.

5. Amin J, Dore GJ, O’Connell DL, et al. Cancer incidence in people with hepatitis $\mathrm{B}$ or $\mathrm{C}$ infection: a large community-based linkage study. J Hepatol. 2006;45:197-203.

6. Strauss R, Torner A, Duberg AS, Hultcrantz R, Ekdahl K. Hepatocellular carcinoma and other primary liver cancers in hepatitis C patients in Sweden - a low endemic country. J Viral Hepat. 2008;15: 531-537.

7. Matsuo K, Kusano A, Sugumar A, Nakamura S, Tajima K, Mueller NE. Effect of hepatitis $\mathrm{C}$ virus infection on the risk of non-Hodgkin's lymphoma: a meta-analysis of epidemiological studies. Cancer Sci. 2004; 95:745-752.

8. Schollkopf C, Smedby KE, Hjalgrim H, et al. Hepatitis C infection and risk of malignant lymphoma. Int J Cancer. 2008;122:1885-1890.

9. Dal ML, Franceschi S. Hepatitis C virus and risk of lymphoma and other lymphoid neoplasms: a meta-analysis of epidemiologic studies. Cancer Epidemiol Biomarkers Prev. 2006;15:2078-2085.

10. Gisbert JP, Garcia-Buey L, Pajares JM, Moreno-Otero R. Prevalence of hepatitis C virus infection in B-cell non-Hodgkin's lymphoma: systematic review and meta-analysis. Gastroenterology. 2003;125:1723-1732.

11. Cooper CL. Obstacles to successful HCV treatment in substance addicted patients. J Addict Dis. 2008;27:61-68.

12. Singal AK, Anand BS. Mechanisms of synergy between alcohol and hepatitis C virus. J Clin Gastroenterol. 2007;41:761-772.

13. Balsano C, Alisi A. Hepatitis C virus (HCV): an RNA virus with a pro-oncogenic potential. Dig Liver Dis. 2007;39 Suppl 1:S46-S51.

14. Craxi A, Laffi G, Zignego AL. Hepatitis C virus (HCV) infection: a systemic disease. Mol Aspects Med. 2008;29:85-95.

15. Blot WJ, McLaughlin JK, Winn DM, et al. Smoking and drinking in relation to oral and pharyngeal cancer. Cancer Res. 1988;48: 3282-3287.

16. Freedman ND, Leitzmann MF, Hollenbeck AR, Schatzkin A, Abnet CC. Cigarette smoking and subsequent risk of lung cancer in men and women: analysis of a prospective cohort study. Lancet Oncol. 2008;9: 649-656.

17. Hart AR, Kennedy H, Harvey I. Pancreatic cancer: a review of the evidence on causation. Clin Gastroenterol Hepatol. 2008;6:275-282.

18. Hashibe M, Brennan P, Benhamou S, et al. Alcohol drinking in never users of tobacco, cigarette smoking in never drinkers, and the risk of head and neck cancer: pooled analysis in the International Head and Neck Cancer Epidemiology Consortium. J Natl Cancer Inst. 2007;99:777-789.

19. Lipworth L, Tarone RE, McLaughlin JK. The epidemiology of renal cell carcinoma. J Urol. 2006;176:2353-2358.

20. Frank L. Epidemiology. When an entire country is a cohort. Science. 2000;287:2398-2399.

21. Andersen TF, Madsen M, Jorgensen J, Mellemkjoer L, Olsen JH. The Danish National Hospital Register. A valuable source of data for modern health sciences. Dan Med Bull. 1999;46:263-268.

22. Storm HH, Michelsen EV, Clemmensen IH, Pihl J. The Danish Cancer Registry - history, content, quality and use. Dan Med Bull. 1997;44:535-539.

23. Patel P, Hanson DL, Sullivan PS, et al. Incidence of types of cancer among HIV-infected persons compared with the general population in the United States, 1992-2003. Ann Intern Med. 2008;148: 728-736.

24. Grulich AE, van Leeuwen MT, Falster MO, Vajdic CM. Incidence of cancers in people with HIV/AIDS compared with immunosuppressed transplant recipients: a meta-analysis. Lancet. 2007;370:59-67. 
25. Rothman KJ, Boice JD. Epidemiologic analyses with a programmable calculator. Department of Health and Human Services publication no 79-1649 (National Institutes of Health) 1979; Washington DC: Goverment Printing Office.

26. Rothman KJ. Analyzing Simple Epidemiologic Data. Epidemiology - An Introduction. 1st ed. New York: Oxford University Press; 2002:130-143.

27. Di M, V, Rufat P, Boyer N, et al. The influence of human immunodeficiency virus coinfection on chronic hepatitis $\mathrm{C}$ in injection drug users: a long-term retrospective cohort study. Hepatology. 2001;34: 1193-1199.

28. Mohsen AH, Easterbrook PJ, Taylor C, et al. Impact of human immunodeficiency virus (HIV) infection on the progression of liver fibrosis in hepatitis C virus infected patients. Gut. 2003;52:1035-1040.

29. Omland LH, Jepsen P, Skinhoj P, et al. The impact of HIV-1 co-infection on long-term mortality in patients with hepatitis $\mathrm{C}$ : a population-based cohort study. HIV Med. 2009;10:65-71.

30. Wiese M, Grungreiff K, Guthoff W, Lafrenz M, Oesen U, Porst H. Outcome in a hepatitis C (genotype 1b) single source outbreak in Germany - a 25-year multicenter study. J Hepatol. 2005;43: 590-598.

31. Obel N, Reinholdt H, Omland LH, Engsig F, Sorensen HT, Hansen AB. Retrivability in The Danish National Hospital Registry of HIV and hepatitis B and $\mathrm{C}$ coinfection diagnoses of patients managed in HIV centers 1995-2004. BMC Med Res Methodol. 2008;8:25.

32. The National Board of Health. Guide to the prevention of viral hepatitis [in Danish]. 2008

33. Lauer GM, Walker BD. Hepatitis C virus infection. $N$ Engl J Med. 2001;345:41-52.
34. Rothman KJ. Biases in Study Design. Epidemiology-An Introduction. 1st ed. New York: Oxford University Press; 2002:94-112.

35. Sorensen HT, Mellemkjaer L, Skriver MV, et al. Fever of unknown origin and cancer: a population-based study. Lancet Oncol. 2005;6:851-855.

36. WHO. World Health Organization. Global status report on alcohol 2004 - Country Profiles. 2010

37. Lok AS, Seeff LB, Morgan TR, et al. Incidence of hepatocellular carcinoma and associated risk factors in hepatitis C-related advanced liver disease. Gastroenterology. 2009;136:138-148.

38. Freedman DS, Tolbert PE, Coates R, Brann EA, Kjeldsberg CR. Relation of cigarette smoking to non-Hodgkin's lymphoma among middle-aged men. Am J Epidemiol. 1998;148:833-841.

39. Morton LM, Hartge P, Holford TR, et al. Cigarette smoking and risk of non-Hodgkin lymphoma: a pooled analysis from the International Lymphoma Epidemiology Consortium (interlymph). Cancer Epidemiol Biomarkers Prev. 2005;14:925-933.

40. Morton LM, Zheng T, Holford TR, et al. Alcohol consumption and risk of non-Hodgkin lymphoma: a pooled analysis. Lancet Oncol. 2005;6:469-476.

41. Talamini R, Polesel J, Montella M, et al. Smoking and non-Hodgkin lymphoma: case-control study in Italy. Int J Cancer. 2005;115:606-610.

42. Amin J, Law MG, Bartlett M, Kaldor JM, Dore GJ. Causes of death after diagnosis of hepatitis B or hepatitis $\mathrm{C}$ infection: a large community-based linkage study. Lancet. 2006;368:938-945.

43. Du WJ, Xiang YT, Wang ZM, et al. Socio-demographic and clinical characteristics of 3129 heroin users in the first methadone maintenance treatment clinic in China. Drug Alcohol Depend. 2008;94:158-164. 
Appendix I ICD-7 codes for subgroups of cancers

\section{Hematological cancers}

Non-Hodgkin lymphoma $(200,202)$

Leukemia (204)

\section{Liver-cancer}

Liver, primary (I55.0)

Liver, not specified as primary (I56)

Alcohol- and tobacco-related cancers

Oropharyngeal (|40-|48)

Esophagus (150)

Colon, including recto sigmoid (153)

Rectum, excluding anus (I54)

Pancreas (157)

Lung (162.0-162.I)

Kidney (180)

Bladder (I8I)
Immune-related cancers

Cervix uteri (I7I)

Melanoma of skin (190)

Other skin (191)

Other cancers*

Gallbladder (I55.I)

Peritoneum and unspecified (I58-159)

Mediastinum (164)

Breast (I70)

Corpus uteri (172)

Ovary (175)

Prostate (177)

Testis (178)

Other and unspecified male genitals (179)

Brain and nervous system (193)

Thyroid (194)

Metastases (198)

Other and unspecified site (199)

\section{Publish your work in this journal}

Clinical Epidemiology is an international, peer-reviewed, open access journal focusing on disease and drug epidemiology, identification of risk factors and screening procedures to develop optimal preventative initiatives and programs. Specific topics include: diagnosis, prognosis, treatment, screening, prevention, risk factor modification, systematic

Submit your manuscript here: http://www.dovepress.com/clinical-epidemiology-journal reviews, risk \& safety of medical interventions, epidemiology \& biostatical methods, evaluation of guidelines, translational medicine, health policies \& economic evaluations. The manuscript management system is completely online and includes a very quick and fair peer-review system, which is all easy to use. 